\title{
FACTORS AFFECTING SCHOOL ABSENCE AMONG SCHOOLGIRLS IN SOUTH TANGERANG, INDONESIA
}

\author{
Faktor yang Mempengaruhi Ketidakhadiran Siswi Sekolah Dasar di \\ Tangerang Selatan, Indonesia
}

\author{
Hoirun Nisa* \\ Study Program of Public Health, Faculty of Health Sciences, Universitas Islam Negeri Syarif Hidayatullah \\ Jakarta \\ Jalan Kertamukti No. 5 Pisangan, Ciputat 15412, Indonesia \\ Telp: (62-21) 74716718, Fax: (62-21) 7404985 \\ E-mail: hoirun.nisa@uinjkt.ac.id
}

Naskah masuk 10 Maret 2019; review 18 April 2019; disetujui terbit 26 Juni 2020

\begin{abstract}
Abstrak
Latar belakang: Remaja perempuan sering memiliki pengetahuan yang kurang mengenai kesehatan reproduksi termasuk menstruasi, dan masalah menstruasi dapat mempengaruhi kehadiran siswi di sekolah. Penelitian ini bertujuan untuk mengetahui faktor yang berhubungan dengan ketidakhadiran siswi sekolah dasar selama masa menstruasi.

Metode: Penelitian cross-sectional dilakukan di sembilan sekolah dasar di Kota Tangerang Selatan. Informasi yang dikumpulkan antara lain karakteristik demografi, umur menarche, durasi menstruasi, dismenore, pengetahuan, dan sumber informasi mengenai menstruasi dari remaja siswi. Partisipan terdiri dari 133 siswi yang telah mengalami menstruasi. Uji chi-square dan regresi logistik digunakan dalam data analisis.

Hasil: Frekuensi siswi yang tidak masuk sekolah saat menstruasi cukup tinggi (19\%). Rata-rata ketidakhadiran sebanyak 2,4 hari setiap siklus menstruasi, dan alasan utama ketidakhadiran di sekolah antara lain takut tembus (69\%), rasa sakit/tidak nyaman (62\%), dan ejekan dari siswa laki-laki (19\%). Pengetahuan yang buruk tentang menstruasi (AOR $=5,24 ; 95 \% C I=1,69-16,30)$ dan dismenore (AOR $=6,05 ; 95 \% C I=1,32-27,69)$ mempunyai hubungan positif yang signifikan dengan ketidakhadiran di sekolah $(p<0,05)$, sementara pendidikan ibu secara signifikan dapat mencegah ketidakhadiran siswi pada masa menstruasi $(p<0,05)$.

Kesimpulan: Faktor-faktor yang mempengaruhi ketidakhadiran siswi di sekolah adalah pengetahuan tentang menstruasi, dismenore, dan status pendidikan ibu. Penelitian ini menunjukkan bahwa memberikan pengetahuan dan manajemen menstruasi dapat bermanfaat dalam mengurangi ketidakhadiran siswi akibat menstruasi di sekolah.
\end{abstract}

Kata kunci: menstruasi, menarche, pengetahuan, ketidakhadiran di sekolah

\begin{abstract}
Background: Adolescent girls often have limited knowledge regarding reproductive health including menstruation, and challenges associated with menstruation may affect girls' school attendance. This study aimed to examine factors associated with school absence during menstruation among schoolgirls.

Method: A cross-sectional study was conducted in nine elementary schools in the South Tangerang City. The information included the schoolgirls' demographic background, menarche age, duration of menstrual, dysmenorrhea, knowledge about menstruation, and source of information related to menstruation. Participants were 133 schoolgirls who had experienced first menstruation. Chi-square test and logistic regression were used for data analysis.

Results: The frequency of schoolgirls who missed school during menstruation was slightly high (19\%). Absentee schoolgirls missed an average of 2.4 days each menstrual cycle, and main reasons for school absence were fear of leakage $(69 \%)$, pain/discomfort (62\%), and boys ridiculed (19\%). Poor knowledge about menstruation (AOR $=5.24 ; 95 \% \mathrm{CI}=1.69-16.30)$ and dysmenorrhea $(\mathrm{AOR}=6.05 ; 95 \% \mathrm{CI}: 1.32-27.69)$ revealed significant positive association with school absence during menstruation $(\mathrm{p}<0.05)$, while mother's education had significantly prevented the schoolgirls from school absence during menstruation $(\mathrm{p}<0.05)$.

Conclusion: Factors affecting school absence of schoolgirls included knowledge of menstruation, dysmenorrhea, and mother's education status. The findings suggest that providing knowledge and menstrual management could benefit on reducing school absenteeism among schoolgirls due to menarche at school.
\end{abstract}

Keywords: menstruation, menarche, knowledge, school absence 


\section{INTRODUCTION}

Menstruation is a natural process that occurs throughout a woman's reproductive life. ${ }^{1}$ Managing the menstrual hygiene, however, can be a challenge for many women and girls, especially in developing countries. ${ }^{2-4}$ Menstruation in adolescence girls is of concern as they enter puberty unprepared and the information they receive is often selective and surrounded by taboos. ${ }^{5,6}$ Many developing countries have developed comprehensive reproductive education policies and contextspecific curricula. However, their full implementation is often hindered by challenges around program planning and roll-out at the national and local level. ${ }^{7}$ In fact, previous studies conducted in Indonesia showed that many adolescent girls had a lack of knowledge about menstruation. ${ }^{8-10}$

Numerous studies have described several challenges associated with menstruation in girls, including poor access to comprehensive information about menstruation, lack of appropriate materials to manage menstrual bleeding, and inadequate facilities to change, clean and dispose absorbents. ${ }^{11}$ These issues may subsequently contribute to increase risks of reproductive health problems. ${ }^{12}$ In addition, inadequate social support can lead to psychosocial consequences such as shame, fear, anxiety and distraction..$^{13}$ Menstruation can also potentially cause school absenteeism. UNICEF estimates that 1 in 10 school age African girls do not attend school during menstruation. ${ }^{14}$ Similarly, several studies indicated that $43 \%$ $50.7 \%$ students were absent from school, ranging from one day to four days because of menstruation. ${ }^{2,4,15}$ In an Ethiopian study, about $58 \%$ of girls stated that their academic performance at school declined after menarche. ${ }^{16}$

Problems encountered by schoolgirls regarding menstruation, especially poor school attendance, may hamper progress towards
Sustainable Development Goals (SDG-3) on good health and well-being, and SDG-4 on quality education. ${ }^{17}$ To date, studies on menstruation among primary schoolgirls are limited in Indonesia. Consequently, the determinants and impacts of menstruation among the schoolgirls, especially on school absence, are not well understood. Thus, this study was to examine the factors associated with school absence during menstruation among primary schoolgirls.

\section{METHODS}

\section{Study design and participants}

A school-based cross-sectional study was conducted to assess menstrual hygienic management among schoolgirls from September to October 2016. The purposive sampling technique was used to select participating schools of four public elementary schools and five private elementary schools in South Tangerang City. Eligible participants were schoolgirls grade $4^{\text {th }}, 5^{\text {th }}$, and $6^{\text {th }}$; aged 912 years; registered in the participating schools; and were able to complete the interview. A total of 602 schoolgirls grade $4^{\text {th }}, 5^{\text {th }}$, and $6^{\text {th }}$ were randomly selected from the participating schools, including 307 schoolgirls from public schools and 295 from private schools. This study was a secondary analysis to data from the menstrual hygienic management survey. The sample size for this study was then calculated that at least 115 participants were required, using the proportion of absence during menstruation of $41 \%^{2}$, power level of $90 \%$, and confidence level of $95 \%$. In this study, however, a total of 133 schoolgirls who had already experienced their first menstruation were included for final analysis. A short 15-minutes briefing was carried out to explain the participants about the terminologies used in the questionnaires such as menstruation, menarche, and dysmenorrhea.

*Corresponding author: hoirun.nisa@uinjkt.ac.id

(C) National Institute of Health Research and Development ISSN: 2354-8762 (electronic); ISSN: 2087-703X (print) 
Permission was obtained from the school authorities prior to data collection. Written consent was obtained from both schoolgirls and their parents. The study protocol was approved by the Research Ethics Committee of the Faculty of Medicine and Health Sciences Universitas Islam Negeri (UIN) Syarif Hidayatullah, Jakarta, Indonesia, Number: Un.01/F10/KP.01.1/KE.SP/04.24.001/2016.

\section{Data collection}

Each participating schoolgirl was interviewed using a structured questionnaire. The information collected included items relating to the schoolgirls' demographic background, and menstrual characteristics (menarche age, duration of menstrual in days, dysmenorrhea, and severity of dysmenorrhea), knowledge about menstruation, and source of information related to menstruation. The schoolgirls' demographic background included age, parent's occupation, parent's education, and type of school.

Schoolgirls' menstrual knowledge score was calculated out of the 10 knowledge specific questions. ${ }^{4}$ Reproducibility was assessed by Cronbach's alpha test $(\alpha \geq 0.70)$. Each correct response earned one point, whereas any wrong response received no point. Knowledge about menstruation was then categorized into poor $(\leq$ 5 correct responses), average (6-7, correct responses) and good ( $\geq 8$ correct responses). Furthermore, the schoolgirls were asked if they missed class during their last three menstrual cycles, the average number of days they were absent per cycle during their last three cycles, and reasons for school absence during menstruation.

\section{Statistical analysis}

Descriptive statistics were conducted to evaluate the mean and standard deviation for continuous data, frequencies and proportions for categorical data. Odds Ratio (OR) and 95\% Confidence Interval (CI) were calculated using logistic regression analysis to ascertain effect sizes for any association between school absence and predictor variables (mother's highest education, dysmenorrhea, knowledge about menstruation, and source of informationrelated menstruation). Multivariable models were adjusted for age, age at menarche (years, continuous) and school type (private or public school). $P$-value was presented as two-sided, and 0.05 were deemed to be significant. Statistical analyses were calculated using SPSS software (SPSS, Inc., version 17).

\section{RESULTS}

Table 1 summarizes the characteristics of schoolgirls. The mean age of schoolgirls was $11.0 \pm 0.1$ years, and more than half of participants $(55.6 \%)$ were students in the private elementary schools. Half of the schoolgirls' mother (54.9\%) and father (53.4\%) education were college or university degree. More than one third (40.6\%) of the mothers of the schoolgirls were housewives and more than half of their fathers $(55.6 \%)$ were government or company officer. The mean age of menarche and duration of menstrual were $10.6 \pm 0.1$ years and $6.7 \pm 0.1$ days, respectively. Majority of the schoolgirls $(66.9 \%)$ reported that they had dysmenorrhea, and half of the schoolgirls $(50.6 \%)$ had mild severity of dysmenorrhea.

In Table 2, around $19 \%$ of out of 133 schoolgirls reported missing school during menstruation. Absentee schoolgirls missed an average of 2.4 days each menstrual cycle. When they were asked for reasons of school absence, $69 \%$ reported that they fear of leakage, $62 \%$ felt pain/discomfort, $19 \%$ reported that boys ridiculed, $11.5 \%$ reported because of limited school sanitation facilities, and $4 \%$ said their guardians forbade them to go to school. Schoolgirls' knowledge of menstruation is presented in Table 2. Majority of participants $(95.5 \%)$ knew correctly that menstruation is a normal biological process. The mean score of the schoolgirls' knowledge of menstruation was $7.5 \pm 1.2$ on a scale of $4-10$. The level of knowledge of menstruation among schoolgirls revealed that $59.4 \%$ had good knowledge, $23.3 \%$ had average knowledge, and $17.3 \%$ had poor knowledge. However, knowledge gap was found in specific areas, i.e. only $16.5 \%$ schoolgirls knew duration of a normal menstrual cycles and $23.2 \%$ of schoolgirls knew about premenstrual symptoms. The leading sources of information were mothers (62.1\%), followed by sisters/friends (22.7\%), and teachers (12.9\%) (Figure 1). 
Table 1. Characteristics of Schoolgirls

\begin{tabular}{|c|c|c|}
\hline Characteristics & Frequency & Percentage \\
\hline Age at interview*, years & 133 & $11.0 \pm 0.1$ \\
\hline \multicolumn{3}{|l|}{ Type of school } \\
\hline Private school & 74 & 55.6 \\
\hline Public school & 59 & 44.4 \\
\hline \multicolumn{3}{|l|}{ Mother's highest education } \\
\hline No school/elementary school & 11 & 8.3 \\
\hline Middle and high schools & 49 & 36.8 \\
\hline College/university & 73 & 54.9 \\
\hline \multicolumn{3}{|l|}{ Mother's occupation } \\
\hline Housewife & 54 & 40.6 \\
\hline Government/company officer & 42 & 31.6 \\
\hline Others & 37 & 27.8 \\
\hline \multicolumn{3}{|l|}{ Father's highest education } \\
\hline No school/elementary school & 16 & 12.0 \\
\hline Middle and high schools & 46 & 34.6 \\
\hline College/university & 71 & 53.4 \\
\hline \multicolumn{3}{|l|}{ Father's occupation } \\
\hline Trade & 46 & 34.5 \\
\hline Government/company officer & 74 & 55.6 \\
\hline Others & 13 & 9.8 \\
\hline Age at menarche*, years & 133 & $10.6 \pm 0.1$ \\
\hline Duration of menstrual, days & 133 & $6.7 \pm 0.1$ \\
\hline \multicolumn{3}{|l|}{ Dysmenorrhea } \\
\hline No & 44 & 33.1 \\
\hline Yes & 89 & 66.9 \\
\hline \multicolumn{3}{|l|}{ Severity of dysmenorrhea } \\
\hline Mild & 45 & 50.6 \\
\hline Moderate & 35 & 39.3 \\
\hline Severe & 9 & 10.1 \\
\hline
\end{tabular}

${ }^{*}$ Data were presented as mean \pm SD

In Table 2, around $19 \%$ of out of 133 schoolgirls reported missing school during menstruation. Absentee schoolgirls missed an average of 2.4 days each menstrual cycle. When they were asked for reasons of school absence, $69 \%$ reported that they fear of leakage, $62 \%$ felt pain/discomfort, $19 \%$ reported that boys ridiculed, $11.5 \%$ reported because of limited school sanitation facilities, and $4 \%$ said their guardians forbade them to go to school. Schoolgirls' knowledge of menstruation is presented in Table 2. Majority of participants (95.5\%) knew correctly that menstruation is a normal biological process. The mean score of the schoolgirls' knowledge of menstruation was $7.5 \pm 1.2$ on a scale of $4-10$. The level of knowledge of menstruation among schoolgirls revealed that $59.4 \%$ had good knowledge, $23.3 \%$ had average knowledge, and $17.3 \%$ had poor knowledge. However, knowledge gap was found in specific areas, i.e. only $16.5 \%$ schoolgirls knew duration of a normal menstrual cycles and $23.2 \%$ of schoolgirls knew about premenstrual symptoms. The leading sources of information were mothers $(62.1 \%)$, followed by sisters/friends $(22.7 \%)$, and teachers (12.9\%) (Figure 1). 
Table 2. School Absence among Schoolgirls

\begin{tabular}{lcc}
\hline \multicolumn{1}{c}{ Indicators } & Frequency & Percentage \\
\hline Absence from school during menstruation & 26 & 18.8 \\
Length of absence, days* $^{*}$ & 26 & $2.4 \pm 2.5$ \\
Reasons for school absence $^{* *}$ & & \\
- Forbidden by family & 1 & 3.9 \\
- Limited school sanitation facilities & 3 & 11.5 \\
- Fear of leakage/staining & 18 & 69.2 \\
- Pain/discomfort & 16 & 61.5 \\
- Boys ridiculed & 5 & 19.2 \\
\hline
\end{tabular}

*Data were presented as mean $\pm \mathrm{SD}$.

** Multiple responses were possible, and the percent is greater than $100 \%$

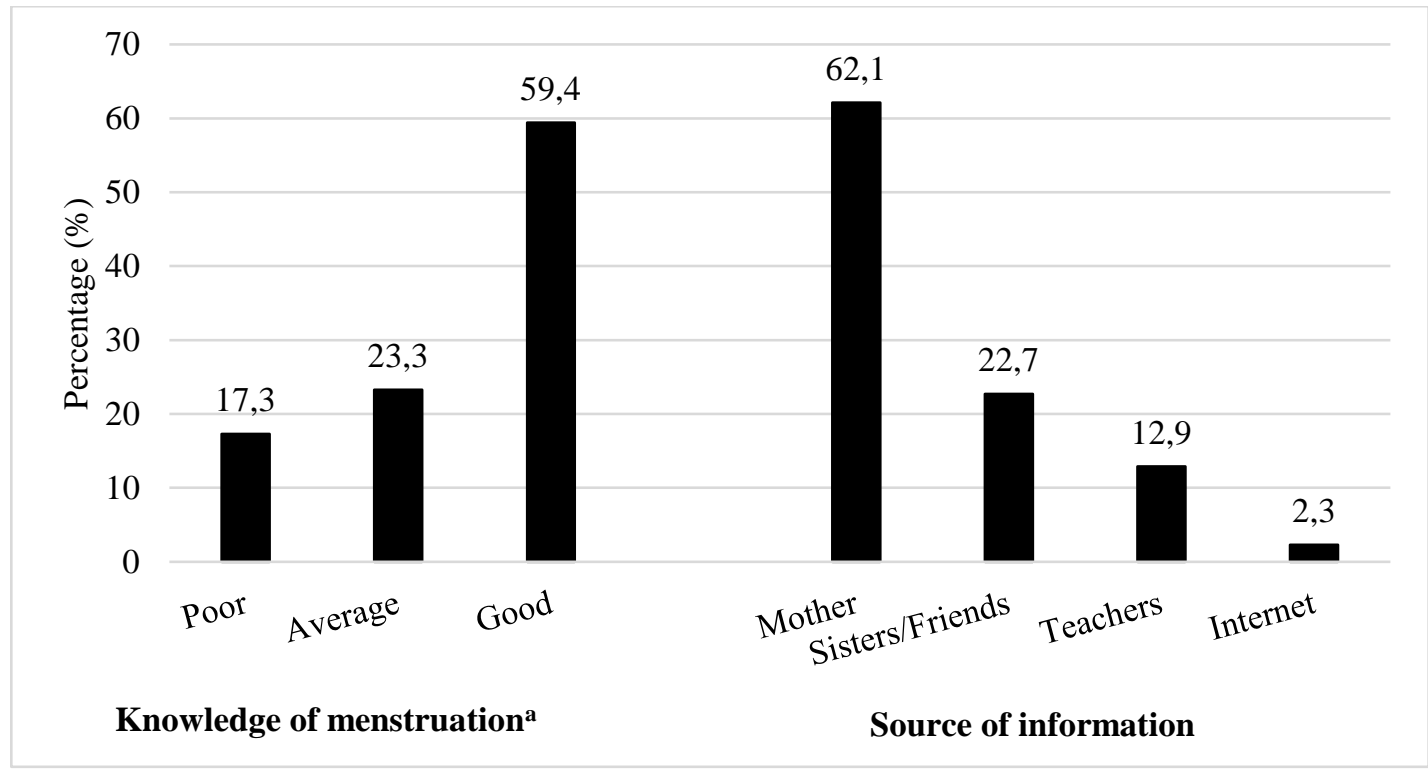

apoor: $\leq 5$ correct responses; average: $6-7$ correct responses; and good: $\geq 8$ correct responses.

Figure 1. Knowledge of Menstruation and Source of Information Related to Menstruation

Furthermore, the OR associated with school absence during menstruation among schoolgirls were calculated as presented in Table 4 . We found that girls whose mothers' highest education were middle school and above were less likely to be absent from school in multivariable analysis, the adjusted OR associated with school absence for mothers' education at middle or high school and college/university were 0.20 and 0.15 , respectively. 
Table 3. Schoolgirls' Knowledge of Menstruation $(n=133)$

\begin{tabular}{lcc}
\hline \multicolumn{1}{c}{ Indicators } & Frequency & Percentage \\
\hline Knew that menstruation is a normal biological process & 127 & 95.5 \\
Knew normal menstrual bleeding duration & 124 & 93.2 \\
Knew duration of a normal menstrual cycle & 22 & 16.5 \\
Became aware that menstruation is due to hormones & 103 & 77.4 \\
Knew about premenstrual symptoms & 31 & 23.2 \\
Knew how to use disposable pads & 132 & 99.2 \\
Became aware that menstrual blood is from uterus & 116 & 87.2 \\
Became aware that menstruation is a sign that a girl biologically can be & 109 & 81.9 \\
pregnant & & 130 \\
Became aware that a girl can go to school during menstruation & 110 & 97.7 \\
Learned menstruation \& its hygienic management in school & 82.7 \\
\hline
\end{tabular}

Dysmenorrhea was 7.32 times more likely to cause girls absent from school. In addition, girls who had poor knowledge about menstruation were 5.98 times more likely to miss schools compared with those who had good knowledge of menstruation. Further adjustment for age, age at menarche, and type of school did not appreciably change the associations $(\mathrm{P}<0.05)$. Source of information regarding menstruation, however, was not significantly associated with school absence among schoolgirls.

Table 4. Factors Associated with School Absence during Menstruation Days among School Girls

\begin{tabular}{lcc}
\hline & Crude OR (95\% CI) & Adjusted OR ${ }^{\mathrm{a}}(95 \% \mathrm{CI})$ \\
\hline Mothers' highest education & 1 (reference) & 1 (reference) \\
No school/elementary school & $0.24(0.06-0.94)^{*}$ & $0.20(0.05-0.84)^{*}$ \\
Middle or high school & $0.10(0.03-0.41)^{*}$ & $0.15(0.03-0.62)^{*}$ \\
College/university & & \\
Dysmenorrhea & 1 (reference) & 1 (reference) \\
No & $7.32(1.64-32.66)^{*}$ & $6.05(1.32-27.69)^{*}$ \\
Yes & 1 (reference) & 1 (reference) \\
Knowledge of menstruation & $1.87(0.60-5.77)$ & $1.97(0.59-6.57)$ \\
Good & $5.98(2.03-17.58)^{* *}$ & $5.24(1.69-16.30)^{* *}$ \\
Average & 1 (reference) & 1 (reference) \\
Poor & $1.36(0.49-3.74)$ & $0.99(0.34-2.90)$ \\
Source of information & $0.74(0.19-2.86)$ & $1.00(0.24-4.09)$ \\
Mother & & \\
Sisters/friends & & \\
Teachers &
\end{tabular}

${ }^{a}$ Adjusted for age (in years), age at menarche (in years), and type of schools (public elementary and private elementary schools); ${ }^{*}$ p-value $<0.05 ;{ }^{* *}$-value $<0.01$. 


\section{DISCUSSION}

In this study, about $19 \%$ of out of 133 schoolgirls reported missing school during menstruation, with an average of 2.4 days each menstrual cycle. The main reasons for school absence were fear of leakage $(69 \%)$, pain/discomfort (62\%), and ridiculed boy (19\%). This study found that educated mothers had a significant effect on girls' school attendance during menstruation. Furthermore, this study found that dysmenorrhea and schoolgirls' knowledge of menstruation were significantly associated with girls' absence from school.

Absentee schoolgirls missed an average of 2.4 days each menstrual cycle, constituting approximately $15 \%$ of the academic year. Although almost all girls (95.5\%) knew that menstruation was a normal biological process, a $17.3 \%$ of schoolgirls had poor knowledge about menstruation. The proportion of poor knowledge in this study was somewhat higher than those in previous studies ${ }^{16,18}$, but was lower than the findings in Bangladesh $(64 \%)^{2}$ and in Western Ethiopia (39.1\%). ${ }^{19}$ In Indonesia, schoolgirls receive very limited reproductive health education through the formal school system. ${ }^{20}$ Discrepancies in the findings can be partly explained by accessibility and availability of information about menstruation.

The schoolgirls' knowledge of menstruation was significantly associated with their school absence during menstruation. Previously several studies have suggested that menstruation affects school attendance. However, one study reported that menstruation had limited impact on school attendance of 198 schoolgirls aged 14.2 years on average. ${ }^{21}$ Apparently, the schoolgirls' age in this study was almost three years younger than that of in the previous study. Thus, this study supports the facts that girls may miss more school days at the beginning of menarche as they may not have fully developed strategies for coping with menstruation. $^{22}$ In addition, multiple intervention trials conducted in Bangladesh ${ }^{23}$ and Ghana ${ }^{24}$ showed that menstrual hygiene education program improved schoolgirls' knowledge of menstruation and increased girls' school attendance by $9 \%$ of a girl's school year. This study found that only few schoolgirls knew duration of a normal menstrual cycles (16.5\%) and knew about premenstrual symptoms (23.2\%), indicating girls' lack of knowledge on how to manage with menstruation. Furthermore, we found that limited school sanitation facilities were one reason for school absence during menstruation, suggesting that improvement of school's sanitation facilities is critical to better prepared schoolgirls to manage menstruation in schools.

Interestingly, this study found that educated mothers had a significant effect on girls' school attendance during menstruation. Several studies reported that mother's education level was important predictors of girls' menstrual knowledge that might affect girls' school attendance. ${ }^{2,19}$ In fact, this study revealed that girls who had poor knowledge about menstruation were more likely to miss schools compared with those who had good knowledge about menstruation. Previous studies have shown that young Indonesian lack basic information on reproductive health topics and often receive information from sources that may be misleading or inaccurate..$^{20}$ In this study, while mothers were the main source of information about menstruation, they may not have sufficient knowledge about menstruation to provide comprehensive and accurate information to girls. In addition, evidence suggests that dysmenorrhea is the most common gynecological complaint in adolescent girl and may result in absences from school. ${ }^{25} \mathrm{~A}$ high prevalent of dysmenorrhea (67\%) in this study was similar with those findings from previous studies. ${ }^{26,27}$ Furthermore, this study found that dysmenorrhea was the leading cause of school absence, suggesting the need for educating schoolgirls on appropriate and effective management of dysmenorrhea and menstruation.

The present findings should be interpreted in the light of some limitations. This study addressed the sensitive issue about menstruation using questionnaire that might have some socialdesirability bias. Another limitation of this study was the cross-sectional nature of data that might limit causal conclusion. The effect of other confounding factors, such as physical exercise, lack of sleep, and parents' socioeconomic status were not considered. However, the present findings have significant implications for adolescent sexual and reproductive interventions in Indonesia. 


\section{CONCLUSION}

The frequency of schoolgirls who missed school during menstruation was slightly high. Factors affecting school absence included knowledge of menstruation, dysmenorrhea, and mother's education status. The findings suggest that providing knowledge and menstrual management prior to menarche, privacy and a positive social environment around menstrual issues has the potential to benefit students by reducing school absence.

\section{RECOMMENDATION}

Health education on menstrual problems targeting schoolgirls and their mothers, and routine screening for menstrual problems by healthcare providers, can help prevent school absenteeism. As mothers were the main source of information and knowledge among schoolgirls in this study, health professionals should involve mothers in general discussions about menstrual problems and how to deal with them.

\section{ACKNOWLEDGMENTS}

We thank the participating school authorities for collaboration and cordial support. We are grateful to the study subjects for their participation in this survey. We also thank the students majoring Epidemiology of the Study Program of Public Health Faculty of Health Sciences UIN for their role in data collecting.

\section{REFERENCES}

1. Symonds, E.M. and L.M. Symonds, Essential Obstetrics and Gynecology. 2004, UK: Churchill Livingstone.

2. Alam, M.U., et al., Menstrual hygiene management among Bangladeshi adolescent schoolgirls and risk factors affecting school absence: results from a cross-sectional survey. BMJ Open, 2017. 7(7): p. e015508.

3. Boosey, R., G. Prestwich, and T. Deave, Menstrual hygiene management amongst schoolgirls in the Rukungiri district of Uganda and the impact on their education: a cross-sectional study. Pan Afr Med J, 2014. 19: p. 253.

4. Davis, J., et al., Menstrual hygiene management and school absenteeism among adolescent students in Indonesia: evidence from a cross-sectional schoolbased survey. Trop Med Int Health, 2018.

5. Jothy, K. and S. KalaiselvI, Is menstrual hygiene and management an issue for the rural adolescent school girls?. Elixir International Journal, 2012. 44: p. 72237228.

6. McMahon, S.A., et al., 'The girl with her period is the one to hang her head' Reflections on menstrual management among schoolgirls in rural Kenya. BMC Int Health Hum Rights, 2011. 11: p. 7.

7. Keogh, S.C., et al., Challenges to implementing national comprehensive sexuality education curricula in low- and middle-income countries: Case studies of Ghana, Kenya, Peru and Guatemala. PLoS One, 2018. 13(7): p. e0200513.

8. Ningsih, E.D. and T.S. Yulianti, The Correlation Knowledgeable About Mentrual With the Anxiety Level on Young Teenage Girl Class VII At SMP Tarakanita Solo Baru Sukoharjo. Indonesian Journal on Medical Science, 2016. 3(1).

9. Nugraheni, S.A., et al., Knowledge and attitudes of elementary students about reproductive health (preliminary study on elementary school in Brebes district, Central Java, Indonesia). International Journal of Community Medicine and Public Health, 2018. 5(4): p. 1298-1303.

10. Susanto, T., et al., Prevalence of factors related to active reproductive health behavior: a cross-sectional study Indonesian adolescent. Epidemiol Health, 2016. 38: p. e2016041.

11. Chandra-Mouli, V. and S.V. Patel, Mapping the knowledge and understanding of menarche, menstrual hygiene and menstrual health among adolescent girls in low- and middle-income countries. Reprod Health, 2017. 14(1): p. 30.

12. Anand, E., J. Singh, and S. Unisa, Menstrual hygiene practices and its association with reproductive tract infections and abnormal vaginal discharge 
among women in India. Sex Reprod Healthc, 2015. 6(4): p. 249-54.

13. Hennegan, J., et al., Measuring the prevalence and impact of poor menstrual hygiene management: a quantitative survey of schoolgirls in rural Uganda. BMJ Open, 2016. 6(12): p. e012596.

14. UNESCO, Puberty education and menstrual hygiene management. 2014; Available from: http://unesdoc.unesco.org/images/0022/00 2267/226792e.pdf-puberty.

15. Miiro, G., et al., Menstrual health and school absenteeism among adolescent girls in Uganda (MENISCUS): a feasibility study. BMC Womens Health, 2018. 18(1): p. 4.

16. Tegegne, T.K. and M.M. Sisay, Menstrual hygiene management and school absenteeism among female adolescent students in Northeast Ethiopia. BMC Public Health, 2014. 14: p. 1118.

17. Nations, U., Sustainable Development Knowledge Platform. Sustainable development goals, 2015. 2015.

18. Gultie, T., D. Hailu, and Y. Workineh, Age of menarche and knowledge about menstrual hygiene management among adolescent school girls in Amhara province, Ethiopia: implication to health care workers \& school teachers. PLoS One, 2014. 9(9): p. e108644.

19. Upashe, S.P., T. Tekelab, and J. Mekonnen, Assessment of knowledge and practice of menstrual hygiene among high school girls in Western Ethiopia. BMC Womens Health, 2015. 15: p. 84.

20. Burnet Institute, Menstrual hygiene management in Indonesia: Understanding practices, determinants and impacts among adolescent schoolgirls, 2015.

21. Oster, E. and R. Thornton, Menstruation, sanitary products, and school attendance: evidence from a randomized evaluation. Am Econ J Appl Econ, 2011. 3: p. 91-100.

22. Crawford, M., L.M. Menger, and M.R. Kaufman, 'This is a natural process': managing menstrual stigma in Nepal. Cult Health Sex, 2014. 16(4): p. 426-39.

23. Haque, S.E., et al., The effect of a schoolbased educational intervention on menstrual health: an intervention study among adolescent girls in Bangladesh. BMJ Open, 2014. 4(7): p. e004607.

24. Montgomery, P., et al., Sanitary pad interventions for girls' education in Ghana: a pilot study. PLoS One, 2012. 7(10): p. e48274.

25. Bernardi, M., et al., Dysmenorrhea and related disorders. F1000Res, 2017. 6: p. 1645.

26. Abdelmoty, H.I., et al., Menstrual patterns and disorders among secondary school adolescents in Egypt. A cross-sectional survey. BMC Womens Health, 2015. 15: p. 70.

27. Nwankwo, T.O., U.U. Aniebue, and P.N. Aniebue, Menstrual disorders in adolescent school girls in Enugu, Nigeria. J Pediatr Adolesc Gynecol, 2010. 23(6): p. 358-63. 